\title{
Military Activities and the Human Environment ${ }^{*}$
}

$\mathrm{T}$ he world faces a problem of truly overriding importance: the problem of conserving the human environment. This problem of maintaining, on a long-term and sustained basis, a human environment in harmony with Nature, has many intertwined facets: botanical, zoological, ecological, agricultural, technological, economic, sociological, demographic, geographical, and cultural-to name only some of the most obvious ones. It is abundantly evident that, with this complexity of components, any hope for coping with that problem will require a wide range of expertise as well as an unprecedented level of cooperation across traditional disciplinary boundaries-especially such as those that separate the natural and social sciences, and those that separate the pure and applied disciplines. The facet of this global problem of environmental protection which is of special interest and concern to me is the military one. In which ways, and to what extent, does the military sector of society hinder the attainment of a sustained balance between humans and Nature? I shall here suggest four major ways in which military factors impinge upon our necessary goal of environmental protection.

First and foremost, I must point to the possibility that a nuclear war will break out between the USA and USSR. If this ever-more-likely catastrophe were, in fact, to occur, then the immediate impact upon the inhabitants and ecosystems of the target countries would be of unprecedented proportions. Additionally, it is becoming ever-more-clear that the long-term impact of a nuclear war would not only multiply the intensity of damage to the human environment of the target countries, but would also spread to many, if not most, other nations on Earth. The predicted widespread devastation of agricultural and more-natural ecosystems would be unprecedented in human history, and would place in jeopardy the very fabric of human society.

Thus, the first priority of environmental protection must be the prevention of nuclear war. This crucial goal is in my view attainable only if the following six actions are taken, and taken before it is too late: (1) the adoption by each nuclear-weapon power of an unqualified no-first-use policy, a deterrence policy that is clearly enunciated and enacted in both words and deeds; (2) a cessation of (a so-called freeze on) all further nuclear-weapon deployment, production, and testing; (3) a reduction in nuclear arsenals by the two superpowers, in recognition that the strategy of deterrence (the only even remotely acceptable justification for possessing nuclear weapons) does not require nuclear-weapon superiority, equality, or even essential parity, but merely sufficiency; (4) the establishment of ever-more nuclear-weapon-free zones such as Antarctica, Latin America, and the South Pacific; (5) the unilateral rejection of nuclear weapons by as many political units as possible (as has recently been done, for example, by New Zealand and Iceland); and, of course (6) the elimination by the nuclear-weapon powers of all nuclear weapons, doing so in recognition of the fact that nuclear weapons are irrational, insane, and simply too anti-social and anti-ecological to employ for any reason-even in retaliation.

Second, I must point to the arms race-that is, to military expenditures-as a major impediment to environmental protection. This is the case for at least three reasons: (a) because the arms race consumes a significant proportion of the world's precious natural resources; (b) because Nature is being disrupted and polluted in the extraction, manufacture, use, and disposal, of these natural resources; and (c) because an extraordinarily high proportion of the world's natural scientists and engineers-perhaps one-third of them-are devoting their talents and energies to developing 'better' weapons rather than to developing better means of environmental protection and similar aspects of human betterment.

Third, I must point again to the extraordinary immensity and complexity of our environmental problem - made up, as it is, of inextricably intertwined ecological, demographic, sociological, political, economic, and yet other, problems. Many of the contributing components of our difficulties are of global dimensions and thus ignore the world's political and ideological divisions. Their immensity, complexity, and lack of respect for national borders, make it imperative that we combine forces in tackling them. It is in this way that military antagonisms provide yet another major impediment to environmental protection.

Fourth and finally, I must point to the environmental disruption that is brought about by conventional warfare. I need hardly remind you that we have archaeological and historical evidence that wars have continued to occur for at least the past nine thousand years. In the words of Arthur Koestler, 'The most persistent sound which reverberates through man's history is the beating of war drums. Tribal wars, religious wars, civil wars, dynastic wars, national wars, revolutionary wars, colonial wars, wars of conquest and of liberation, wars to prevent and to end all wars, follow each other in a chain of compulsive repetitiveness as far as man can remember his past, and there is every reason to believe that the chain will extend into the future.'

It is abundantly evident that where the will, the technical and industrial capacity or external aid, and the time all exist, warfare wreaks extraordinary levels of death and suffering, of material destruction, and of environmental damage plus ecological disruption. Indeed, there have been recent military demonstrations of the growing attractiveness of environmental devastation as an intentional strategy of war. As a case in point, the Second Indochina War (or Viet Nam Conflict) of 1961-75 represents not only the culmination to date of an ever-greater technical ability to destroy large areas with efficiency by so-called conventional means, but also the actual desire to do so as an approach to subduing an enemy. In conclusion, at a time when the major threats to national security and global well-being are environmental in nature, it is ironical that we continue to direct so much tangible and intangible effort into the military sector of society. This huge allocation of material and intellectual resources would serve us better if conserved or diverted to the civil sector $-\mathbf{a}$ suggestion that seems to me no longer arguable in this age of nuclear weaponry.

\author{
Arthur H. WeSting, Senior Research Fellow \\ Stockholm International Peace Research Institute (SIPRI) \\ Pipers Väg 28, S-171 73 Solna, Sweden; \\ Adjunct Professor of Ecology, \\ Hampshire College, Amherst, Massachusetts, USA.
}

\footnotetext{
* Based on an invited 'introduction of theme' (originally entitled 'The Imperative of Avoiding Nuclear Holocaust') delivered at the Annual General Meeting of the World Council For The Biosphere and its joint planning sessions with the International Society For Environmental Education, held at the Hôtel de Sonloup, 1833 Les Avants sur Montreux, Switzerland, during 18-22 June 1985-see also pp. 2811-2 of this issue. Ed. Ed
} 